\title{
Investigation of the Effects of Smoking Addiction and Physical Activity on Some Respiratory Functions in Young Adult Males
}

\author{
Muhammed Fatih Bilici ${ }^{1}$, Ali Türker ${ }^{1}$ \\ ${ }^{1}$ Muş Alpaslan University, School of Physical Education and Sports, Turkey \\ Correspondence: Muhammed Fatih Bilici, School of Physical Education and Sports, Turkey.
}

Received: October 28, 2019

Accepted: November 11, 2019

Online Published: November 18, 2019

doi:10.11114/jets.v7i12.4585

URL: https://doi.org/10.11114/jets.v7i12.4585

\begin{abstract}
The aim of the study is to investigate the effect of smoking addiction and physical activity on some respiratory functions in young adult males. 120 male students who have no health problem with an age average of 21,00 (years), height average of $174,2(\mathrm{~cm})$ and weight average of $69,62(\mathrm{~kg})$ have voluntarily participated in the study. The students participating in the study have been categorized according to their condition of doing exercise and addiction to smoking. Spirometer (Pony Fx, Italy) was used to determine pulmonary functions of students. In the statistical analysis of the obtained data SPSS program has been used. The normality distribution of the data has been identified with Shapiro-Wilk test. In the analysis of the data which have no normal distribution, Kruskal Wallis test and in the sub groups Mann- Whitney U test has been used. It has been determined that FVC, FEV1, FEF25-75\% (L/s), PEF (L/s), VC and MVV values of the student groups who doing regular exercise are significantly higher than the student groups who do not $(\mathrm{p}<0,05)$. No statistically significant difference has been found in $\mathrm{FEV} 1 / \mathrm{FVC}(\%)$ value among the groups $(p>0,05)$. It has been found that smoking addiction is effective on PEF value in a significant level $(p<0,05)$.
\end{abstract}

Keywords: respiratory functions, exercise, smoking addiction

\section{Introduction}

Sportive activities, because of their physical and physiological advantages, are one of the important social activities that people prefer for a suitable physical structure and to protect general health (Kürkçü \& Gökhan, 2011). Regular exercises directly affect physical and physiological development. Exercise and physical activity which are highly important for the development of a healthy physical structure contribute to the development of many systems in the body and the functioning of those systems in a healthy way. Respiratory system is one of the systems that exercise and physical activity directly affect (Alpay et al., 2007).

In many previous studies, it has been identified that long term and regular exercises develop respiratory functions(Doherty \& Dimitriou, 2007; Vaithiyanadane et al., 2012). Likewise, in the literature, it is possible to encounter many studies determining that respiratory functions spoil because of smoking habits (Mehta et al., 2016). However, it has still been a debate how those both factors together effect respiratory functions.

Determining the effect of cigarette dependence on respiratory functions, which causes many fatal diseases, is very important for sports performance (Trinder et al., 2000). The aim of the study is to investigate the effect of exercise and smoking addiction factors to evaluate separately in addition to the effect of both factors together on some respiratory functions of young adult males.

\section{Method}

\subsection{Research Group}

A total of 120 male students studying in Muş Alparslan University who have no health problem and with an age average of 21,00 (years), height average of 174,2 (cm) and weight average of 69,62 (kg) have voluntarily participated to our study. Those students have been categorized to their condition of doing sports and smoking habits. The student groups who are addictive to smoking have been created by the students smoking through at least 4 years, who are not addicted to any drugs except cigarette and do not drink alcohol. The student groups who do exercises have been selected by the students who have done sports in different sport branches for at least 3 years and still do sports regularly at least 1 hour everyday of 5 days in a week. 


\subsection{Spirometric Measurements}

The functional condition of respiratory tract can be identified classically with measuring lung volume and capacities (Atan et al., 2013). The respiratory function tests of the participant students in the study have been made with Pony Fx spirometer. Before the test has been conducted the students have been informed about that they should not smoke cigarette at least 1 hour before the test, should not drink alcohol at least 4 hour before, should avoid heavy exercise, should not wear tight clothes, should not eat heavy dishes 2 hours before and should not take bronchodilator pills. The total measurements have been performed when the individual is in the sitting position having closed nose with a band grip by making a few aspirations in breath volume connected to spirometer with a mouthpiece after it is ensured that he gets used to this kind of breathing. Each measurement has been repeated 3 times and the best value has been recorded.

\subsection{Analysis of Data}

In statistical analysis of the obtained data SPSS program has been used. The normality distribution of the data has been determined with Shapiro-wilk test. Kruskal Wallis test has been used in the analysis of the data which do not have normality distribution and in the sub groups Mann-Whitney $\mathrm{U}$ test has been used.

\section{Results}

Table 1. BMI values of young adult males

\begin{tabular}{|c|c|c|c|c|c|c|c|c|c|}
\hline Parameters & & Groups & $\mathbf{N}$ & Avr. & S.D & $\begin{array}{l}\text { R. } \\
\text { Avr. }\end{array}$ & Chi-Square & $\mathbf{P}$ & Direction of difference \\
\hline \multirow{4}{*}{$\begin{array}{l}\text { BMI } \\
(\mathrm{kg} / \mathrm{m} 2)\end{array}$} & 1 & $\begin{array}{l}\text { Ones who doing } \\
\text { sports }\end{array}$ & 42 & 22,73 & 2,54 & 65,45 & \multirow{4}{*}{3,604} & \multirow{4}{*}{0,308} & \multirow{4}{*}{$\mathrm{p}>0,05$} \\
\hline & 2 & $\begin{array}{l}\text { Ones who doing } \\
\text { sports \& Smoker }\end{array}$ & 27 & 21,75 & 1,72 & 50,70 & & & \\
\hline & 3 & $\begin{array}{l}\text { Ones who don't do } \\
\text { sports }\end{array}$ & 26 & 22,75 & 2,35 & 66,67 & & & \\
\hline & 4 & $\begin{array}{l}\text { Ones who don't do } \\
\text { sports \& Smoker }\end{array}$ & 27 & 22,84 & 3,80 & 61,17 & & & \\
\hline
\end{tabular}

The respiratory functions show an alteration according to gender, age, height, weight and body sizes (Tartibain and Birami, 2010). When examining Table 1, there is not a significant difference statistically between the values of the groups' body max index that is to say it has been seen that there is a homogeneous distribution among the groups.

Table 2. Tests of Normality

\begin{tabular}{l|c|c|c}
\hline \multirow{2}{*}{ Parameters } & \multicolumn{3}{c}{ Shapiro-Wilk } \\
\cline { 2 - 4 } & Statistic & df & Sig. \\
\hline BMI (kg/m2) &, 960 & 122 &, 001 \\
\hline FVC(L) &, 992 & 122 &, 036 \\
\hline FEV1(L) &, 984 & 122 &, 015 \\
\hline FEV1/FVC (\%) &, 972 & 122 &, 013 \\
\hline PEF (L/s) &, 966 & 122 &, 004 \\
\hline FEF25-75\% (L/s) &, 770 & 122 &, 000 \\
\hline VC (L) &, 958 & 122 &, 001 \\
\hline MVV (L/min) &, 970 & 122 &, 009 \\
\hline
\end{tabular}

When examining Table 2, it is seen that parameters of respiratory function do not show normal distribution. 
Table 3. Some respiratory functional values and analysis of young males

\begin{tabular}{|c|c|c|c|c|c|c|c|c|c|}
\hline Parameters & & Groups & $\mathbf{N}$ & Avr. & S.D. & $\begin{array}{l}\text { Ranking } \\
\text { avarage }\end{array}$ & Chi-Square & $\mathbf{P}$ & Direction of Difference \\
\hline \multirow{5}{*}{ FVC(L) } & 1 & Ones who doing sports & 42 & 5,30 & 0,54 & 72,12 & \multirow{5}{*}{14,698} & \multirow{5}{*}{0,002} & \multirow{5}{*}{$1-3,1-4,2-3,2,4$} \\
\hline & 2 & $\begin{array}{l}\text { Ones who doing sports } \\
\& \text { Smoker }\end{array}$ & 27 & 5,35 & 0,69 & 72,22 & & & \\
\hline & 3 & $\begin{array}{llll}\begin{array}{l}\text { Ones } \\
\text { sports }\end{array} & \text { who don't do } \\
\end{array}$ & 26 & 4,80 & 0,57 & 45,08 & & & \\
\hline & 4 & $\begin{array}{l}\text { Ones who don't do } \\
\text { sports \& Smoker }\end{array}$ & 27 & 4,86 & 0,78 & 50,07 & & & \\
\hline & & Total & 122 & 5,11 & 0,67 & & & & \\
\hline \multirow{5}{*}{ FEV1(L) } & 1 & Ones who doing sports & 42 & 4,58 & 0,56 & 75,27 & \multirow{5}{*}{17,373} & \multirow{5}{*}{0,001} & \multirow{5}{*}{$1-3,1-4, \quad 2,4$} \\
\hline & 2 & $\begin{array}{l}\text { Ones who doing sports } \\
\text { \& Smoker }\end{array}$ & 27 & 4,50 & 0,57 & 69,59 & & & \\
\hline & 3 & \begin{tabular}{llll|}
$\begin{array}{l}\text { Ones } \\
\text { sports }\end{array}$ & who don't do \\
\end{tabular} & 26 & 4,11 & 0,54 & 46,60 & & & \\
\hline & 4 & $\begin{array}{l}\text { Ones who don't do } \\
\text { sports \& Smoker }\end{array}$ & 27 & 4,07 & 0,69 & 46,33 & & & \\
\hline & & Total & 122 & 4,35 & 0,63 & & & & \\
\hline \multirow{5}{*}{$\begin{array}{l}\text { FEV1/FVC\% } \\
(\%)\end{array}$} & 1 & Ones who doing sports & 42 & 86,39 & 5,72 & 70,00 & \multirow{5}{*}{4,165} & \multirow{5}{*}{0,244} & \multirow{5}{*}{$p>0,05$} \\
\hline & 2 & $\begin{array}{l}\text { Ones who doing sports } \\
\& \text { Smoker }\end{array}$ & 27 & 84,44 & 6,43 & 58,15 & & & \\
\hline & 3 & $\begin{array}{llll}\begin{array}{l}\text { Ones } \\
\text { sports }\end{array} & \text { who don't do } \\
\end{array}$ & 26 & 85,49 & 6,11 & 59,69 & & & \\
\hline & 4 & $\begin{array}{l}\text { Ones who don't do } \\
\text { sports \& Smoker }\end{array}$ & 27 & 83,84 & 6,68 & 53,37 & & & \\
\hline & & Total & 122 & 85,20 & 6,19 & & & & \\
\hline \multirow{5}{*}{ PEF (L/s) } & 1 & Ones who doing sports & 42 & 8,82 & 1,13 & 83,88 & \multirow{5}{*}{34,817} & \multirow{5}{*}{0,000} & \multirow{5}{*}{$1-2,1-3,1-4,2-4,3-4$} \\
\hline & 2 & $\begin{array}{l}\text { Ones who doing sports } \\
\text { \& Smoker }\end{array}$ & 27 & 7,97 & 1,72 & 62,94 & & & \\
\hline & 3 & $\begin{array}{llll}\begin{array}{l}\text { Ones } \\
\text { sports }\end{array} & \text { who don't do } \\
\end{array}$ & 26 & 7,53 & 1,20 & 52,27 & & & \\
\hline & 4 & $\begin{array}{l}\text { Ones who don't do } \\
\text { sports \& Smoker }\end{array}$ & 27 & 6,38 & 1,84 & 34,13 & & & \\
\hline & & Total & 122 & 7,82 & 1,71 & & & & \\
\hline \multirow{5}{*}{$\begin{array}{l}\text { FEF25-75\% } \\
(\mathrm{L} / \mathrm{s})\end{array}$} & 1 & Ones who doing sports & 42 & 5,22 & 1,16 & 74,95 & \multirow{5}{*}{13,200} & \multirow{5}{*}{0,004} & \multirow{5}{*}{$1-3,1-4,2-4$} \\
\hline & 2 & $\begin{array}{l}\text { Ones who doing sports } \\
\& \text { Smoker }\end{array}$ & 27 & 4,89 & 0,94 & 63,11 & & & \\
\hline & 3 & $\begin{array}{llll}\begin{array}{l}\text { Ones } \\
\text { sports }\end{array} & & & \\
\end{array}$ & 26 & 5,02 & 2,57 & 56,04 & & & \\
\hline & 4 & $\begin{array}{l}\text { Ones who don't do } \\
\text { sports \& Smoker }\end{array}$ & 27 & 4,32 & 1,02 & 44,22 & & & \\
\hline & & Total & 122 & 4,91 & 1,53 & & & & \\
\hline \multirow{5}{*}{ VC (L) } & 1 & Ones who doing sports & 42 & 5,06 & 0,52 & 73,86 & \multirow{5}{*}{13,959} & \multirow{5}{*}{0,003} & \multirow{5}{*}{$1-3,1-4,2-3$} \\
\hline & 2 & $\begin{array}{l}\text { Ones who doing sports } \\
\text { \& Smoker }\end{array}$ & 27 & 5,00 & 0,66 & 68,13 & & & \\
\hline & 3 & $\begin{array}{llll}\begin{array}{l}\text { Ones } \\
\text { sports }\end{array} & \text { who don't do } \\
\end{array}$ & 26 & 4,45 & 0,76 & 44,73 & & & \\
\hline & 4 & $\begin{array}{l}\text { Ones who don't do } \\
\text { sports \& Smoker }\end{array}$ & 27 & 4,71 & 0,99 & 51,80 & & & \\
\hline & & Total & 122 & 4,84 & 0,76 & & & & \\
\hline \multirow{5}{*}{ MVV (L/min) } & 1 & Ones who doing sports & 42 & 143,57 & 20,71 & 82,69 & \multirow{5}{*}{23,938} & & \\
\hline & 2 & $\begin{array}{l}\text { Ones who doing sports } \\
\& \text { Smoker }\end{array}$ & 27 & 126,68 & 26,49 & 55,72 & & & \\
\hline & 3 & $\begin{array}{llll}\begin{array}{l}\text { Ones } \\
\text { sports }\end{array} & \text { who don't do } \\
\end{array}$ & 26 & 120,31 & 17,95 & 48,02 & & 0,000 & $1-2,1-3,1-4$ \\
\hline & 4 & $\begin{array}{l}\text { Ones who don't do } \\
\text { sports \& Smoker }\end{array}$ & 27 & 114,26 & 32,16 & 47,30 & & & \\
\hline & & Total & 122 & 128,39 & 26,91 & & & & \\
\hline
\end{tabular}


When examining Table 3, it has been determined that FVC, FEV1, FEF25-75\% (L/s), VC and MVV values of the groups who do sports are significantly higher than the groups who do not $(\mathrm{p}<0,05)$. No significant difference in FEV1/FVC (\%) values has been found among the groups ( $>>0,05)$. It has been also determined that PEF (L/s) value of the group doing sports is statistically higher than other groups in a significant level $(p<0,05)$, PEF $(\mathrm{L} / \mathrm{s})$ value of the group doing sports and smoking addictive is statistically higher than sedentary group in a significant level $(p<0,05)$ and $\mathrm{PEF}(\mathrm{L} / \mathrm{s})$ value of the sedentary group is statistically higher than sedentary group with smoking addiction in a significant level $(\mathrm{p}<0,05)$.

\section{Discussion and Conclusion}

FVC and FEV1 values decrease when there is contraction or obstruction in airways. FEV1 value is more related to big airways. According to our research results, it has been identified that FVC and FEV1 values of the student groups doing sports is significantly higher than the student groups who do not do sports $(\mathrm{p}<0,05)$. Also, it has been determined that there is no statistically significant difference in FVC and FEV1 values between the student groups doing sports with smoking addiction and the student group who do not smoke but do sports $(\mathrm{p}>0,05)$.

It has been established in many studies that long term and regular exercises develop respiratory muscles and increase respiratory function capacity (Robinson et al., 1982; Johnson et al., 1996; Gökdemir et al., 2007; Sable et al., 2012; Ahmadi et al., 2013). In the study aimed at identifying the respiratory function capacity of the swimmers and sedentary groups, it has been determined that FVC and FEV1 values of the swimmers are higher than the sedentary groups (Vaithiyanadane et al., 2012). In another study conducted on athletes and swimmers it has been determined that FVC and FEV1 values of the athletes and swimmers are statistically higher than the sedentary groups in a significant level (Doherty \& Dimitriou, 2007). According to our study findings we can state that regular exercise in young adult males develop tough vital capacity and increase the functioning of big airways. Findings of many studies in literature have determined that regular exercise develops respiratory functions and supported our study results.

In some studies, it has been determined that smoking directly effects lung functions negatively, smoking addiction causes big and medium airways tighten, this tightening is directly proportional with smoking duration (Tecimer et al., 1995; Boskabaday et al., 2011). In another study, it has been determined that there is a significant relationship between decrease in respiratory functions and smoking duration (Burrows et al., 1977). In a study conducted on sedentary groups in India, it has been identified that respiratory functions of smoking addictive's spoil relatively 17.3 times more compared to the ones who do not smoke (Rubeena et al., 2009). Unlike those studies mentioned above, in our study findings no statistically significant difference in FVC and FEV1 values according to the smoking addiction factor between the groups. We consider that this situation is because the positive effect of sport comes into prominence rather than the negative effect of cigarette.

FEV1/FVC\% (\%) value is an important parameter used in identifying restrictive lung diseases like respiratory insufficiencies and the occlusion in airways found in lungs (Demir, 2017). In our study findings, it has not been found that there is statistically significant difference in FEV1/FVC\% (\%) value according to smoking addiction and exercise variables among the groups $(\mathrm{p}>0,05)$.

PEF (L/s) value shows big airway functions. According to our study findings, it has been stated that there is statistically significant difference in PEF (L/s) value according to both exercise and smoking addiction variables among the groups. Özkurt et al. (2000) have determined in their study that PEF value of the individuals who smoke is statistically lower in a significant level than the ones who do not. According to those results, it can be said that physical activity heals big airway functions in lungs and on the other hand smoking cigarette damages prominently to big airway functions.

FEF25-75\% (L/s) value informs about medium and small scale obstruction in bronchus. In a study researching the effect of low density and long term exercise performed by sportsmen and sedentary groups who smoke cigarettes and hookah on respiratory functions, it has been stated that exercise has increased FEF25-75\% (L/s) value in both sportsmen who smoke cigarettes and sedentary groups (Kouba, et al., 2015). In our study results, the reason why FEF25-75\% (L/s) value of both groups who do sports is statistically higher in a significant level than all other has shown the positive effect of sport.

MVV value decreases in the conditions when respiratory resistance increases in individuals, respiratory muscles are affected, lung and thorax compliances increase and decrease, respiratory control mechanisms break down (Günay et al., 2005). Mazic et al. (2015) have stated in their study that MVV and VC values of sportsmen in different branches compared to sedentary groups are higher in a significant level. In a study conducted on healthy adults, it has been determined that exercise has changed VC and MVV values (George et al., 2014). According to results obtained in our study, it has been stated that VC and MVV values of the groups who do sports are higher compared to other groups. This situation shows that the positive effect of sport is at the forefront. 
According to results of our study, it has been identified that the groups who do sports have higher air volume in big and small airway in lungs compared to sedentary groups. In this population, when considering the effect of sport performed with smoking on respiratory functions it can be said that the positive effect of exercise on respiratory muscles is determinant rather than the negative effect of cigarette. Accordingly it can be said that exercise and sport do not prevent the damage of cigarette to lungs but they make this damage invisible with their positive effect on respiratory functions.

Note: This study has been supported by the department of Scientific Research Projects, Muş Alparslan University.

\section{References}

Ahmadi, F., Zar, A., Dalvand, H., \& Salesi, M. (2013). Effect of eight week endurance training on pulmonary function in sedentary men. International Journal of Basic Sciences \& Applied Research, 2(4), 405-411.

Alpay, B., Altuğ, K., \& Hazar, S. (2007). İlköğretim okul takımlarında yer alan 11-13 grubu öğrencilerin bazı solunum ve dolaşım parametrelerinin spor yapmayan öğrencilerle karşılaştırılarak değerlendirilmesi. Mehmet Akif Ersoy Üniversitesi Eğitim Fakültesi Dergisi, 8(17), 22-29.

Atan, T., Akyol, P., \& Çebi, M. (2013). Bireysel sporla uğraşan yıldızlar kategorisindeki sporcuların solunum

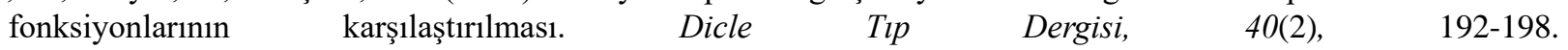
https://doi.org/10.5798/diclemedj.0921.2013.02.0253

Boskabady, M., Mahmodinia, M., \& Boskabady, M. (2011). Pulmonary function tests and respiratory symptoms among smokers in the city of mashhad (north east of Iran). Rev Port Pneumol., 17(5), 199-204. https://doi.org/10.1016/j.rppneu.2011.05.001

Burrows, B., Knudson, R., Cline, M., \& Lebowitz, M. (1977). Quantitative relationship between cigarette smoking and ventilatory function. Am Rev Respir Dis, 115(2), 195-205.

Demir, T. (2017). Spirometry and flow-volume curve. Toraks Cerrahisi Bülteni, 10, 9-15. https://doi.org/10.5578/tcb.2017.002

Doherty, M., \& Dimitriou, L. (2007). Comparison of lung volume in Greek swimmers, land based athletes, and sedentary controls. Br J Sports Med., 31, 337-341. https://doi.org/10.1136/bjsm.31.4.337

George, J., Sen, K., \& Raveendran, C. (2014). Evaluation of the effect of exercise on pulmonary function in young healthy adults. IJBAR, 5(6), 308-312.

Gökdemir, K., Koç, H., \& Yüksel, O. (2007). Aerobik antrenman programının üniversite öğrencilerinin bazı solunum ve dolasım parametreleri ile vücut yağ oranı üzerine etkisi. Egzersiz, 1, 145-149.

Günay, M., Tamer, K., \& Cicioğlu, İ. (2005). Spor fizyolojisi ve performans ölçümü. Ankara: Gazi Kitabevi.

Johnson, B., Aaron, E., Babcock, M., \& Dempsey, J. (1996). Respiratory muscle fatigue during exercise: implications for performance. Med Sci Sports Exercise, 28, 1129-1137. https://doi.org/10.1097/00005768-199609000-00008

Kouba, A., Triki, M., Trabelsi, H., Masmoudi, L., Zeghal, K., Sahnoun, Z., \& Hakim A. (2015). Effect of low- intensity continuous training on lung function and cardiorespiratory fitness in both cigarette and hookah smokers. African Health Sciences, 15(4), 1170-1181. https://doi.org/10.4314/ahs.v15i4.16

Kürkçü, R., \& Gökhan, İ. (2011). Hentbol Antrenmalarının 10-13 Yaş Grubu Öğrencilerin Bazı Solunum ve Dolaşım Parametreleri Üzerine Etkilieri. Uluslararası İnsan Bilimleri Dergisi, 8(1), 135-143.

Mazic, S., Lazovic, B., Djelic, M., Lazic, J., Saranovic, S., Durmic, T., et al. (2015). Respiratory parameters in elite athletes-does sport have an influence? Rev Port Pneumol, 21(4), 192-197. https://doi.org/10.1016/j.rppnen.2014.12.003

Mehta V, Desar N, Patel S. (2016). When Pulmonary Function Test is Available, Should we Wait for the COPD Symptoms to Develop, Journal of Clinical and Diagnostic Research, 10(10), OE08-OE12. https://doi.org/10.7860/JCDR/2016/21006.8705

Özkurt, S., Bostancı, M., Altın, R., Özşahin, A., \& Akdağ, B. (2000). Tıp fakültesi çalışanlarında sigara içme prevalansı, nikotin bağımlılığı ve solunum fonksiyon testleri. Tüberküloz ve Toraks Dergisi,48(2), 40-147.

Robinson, E., \& Kjeldgard, J. (1982). Improvement in ventilatory muscle function with running. J Appl Physiol, 52, 1400-1406. https://doi.org/10.1152/jappl.1982.52.6.1400

Rubeena, B., Mahagaonkar, A., \& Kulkarni, N. (2009). Study of pulmonary function tests among smokers and non-smokers in a rural area. Pravara Med Rev, 4(1), 11-15.

Sable, M., Vaidya, S., \& Sable, S. (2012). Comparative study of lung functions in swimmer and runners. Indian J 
Physiol Pharmacol, 56(1), 100-104.

Tartibain, B., \& Birami, M. (2010). Acute ventilatory rensponses to intensive aerobik egxercise in healthy young boys aged 13-16 years: relationship to anthropometric factor. Physical Activity \& Physiology Journal, N(4), 297-304.

Tecimer, Ç., Üstün, M., \& Aladağ, M. (1995). Lökosit ve trombosit sayıları, sigara içme ve akciğer fonksiyonları arasındaki ilişki. Tüberküloz ve Toraks, 43(4), 203-211.

Trinder, P. M., Croft, P. R., \& Lewis, M. (2000). Social class, smoking and the severity of respiratory symptoms in the general population. Journal of Epidemiology and Community Health, 54, 340-343. https://doi.org/10.1136/jech.54.5.340

Vaithiyanadane, V., Sugapriya, G., Saravanan, A., \& Ramachandran, C. (2012). Plumonary function test in swimmers and non-swimmers-a comparative study. Int. J. Biol. Med. Res., 3(2), 1735-1738.

\section{Copyrights}

Copyright for this article is retained by the author(s), with first publication rights granted to the journal.

This is an open-access article distributed under the terms and conditions of the Creative Commons Attribution license which permits unrestricted use, distribution, and reproduction in any medium, provided the original work is properly cited. 